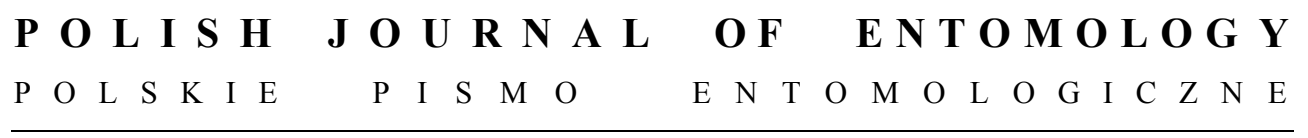

VOL. 81: $331-334$

Gdańsk

31 December 2012

DOI: $10.2478 / \mathrm{v} 10200-012-0013-\mathrm{z}$

\title{
The westernmost record of Euclasta splendidalis (HERRICH-SCHÄFFER, 1848) (Lepidoptera: Crambidae) in Europe
}

\section{TONI KOREN}

University of Primorska, Science and Research Centre, Institute for Biodiversity Studies, SI-6310 Izola, Giordana Bruna 6, Slovenia, e-mail: koren.toni1@gmail.com

\begin{abstract}
During research in the Neretva Valley, south-western Croatia, a new species Euclasta splendidalis - was reported for the Croatian fauna. Several specimens were collected in August at two localities, close to Rogotin and Opuzen. The closest known record of this species lies $380 \mathrm{~km}$ to the south-east in the Federative Republic of Macedonia. With this record the known range of the species has significantly extended westwards.
\end{abstract}

KEY WORDS: Euclasta splendidalis, moths, Croatia, Neretva, distribution.

\section{INTRODUCTION}

Several specimens of Euclasta splendidalis (HERRICH-SCHÄFFER, 1848) were recorded during a three-day field trip to the lower Neretva Valley, southern Croatia (Fig. 1). The localities where it was recorded were (Fig. 1):

1. Kamp Rio, Opuzen, karstic slopes on one side and swampy, boggy grassland and marshland on the other, 43.014925, 17.468594, 6.8.2012, 3 exx.

2. $500 \mathrm{~m} \mathrm{~S}$ of Rogotin, karstic slopes on one side and swamp, boggy grassland and marshland on the other, 43.039913, 17.476838, 7.8.2012, 3 exx.

The moths were attracted to a light trap, consisting of two TLD 15W UV lamps, powered by a $12 \mathrm{~V}$ battery. The lamps were connected to a metal pyramid, covered with a white sheet. The moths were collected over a period of three hours, from 21:00 to 24:00 hrs. The moths were set, and then stored in a private collection (Koren, Pazin). Identification was carried out using LERAUT (2012), and the genitalia were checked according to POPESCU-GoRJ \& CONSTANTINESCU (1973). The systematics follow Nuss 
et al. (2011). The map was produced using a combination of maps from Fauna Europaea (2011) and Google Earth.

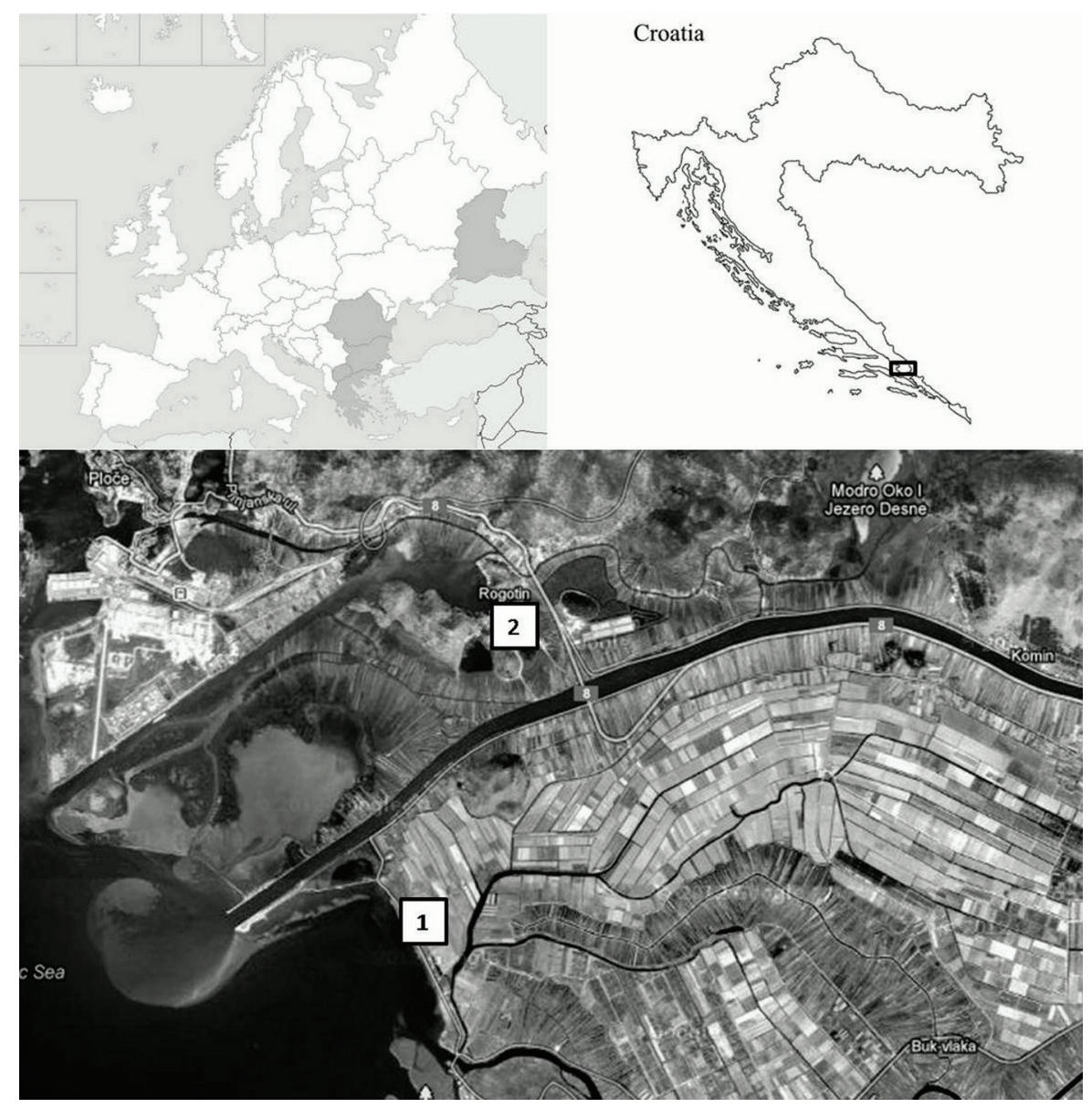

Fig. 1. Upper left corner - known distribution of Euclasta splendidalis in Europe, upper right corner map of Croatia with the area of the River Neretva marked, lower map: the Neretva delta with the records marked.

\section{DISTRIBUTION}

The genus Euclasta LEDERER, 1855 belongs to the large and widespread family Crambidae. The genus itself is relatively small, with approximately 17 species described (Nuss et al. 2003-2011). The members of this genus inhabit Africa, Australia, Europe and Asia. Only two species are present in Europe: Euclasta splendidalis (HERRICH-SCHÄFFER, 
1848) and Euclasta varii POPESCU-GORJ \& CONSTANTINESCU, 1973. E. splendidalis was first described from Turkey (HERRICH-SCHÄFFER 1847-1855), but was later recorded in Asia Minor, Transcaucasia, eastern Asia, Bulgaria and Macedonia (KLIMESCH 1964). It has also been recorded from Romania, Greece and southern Russia (NUSS et al. 2011).

Later, a species originating from western Europe and north Africa was described as a separate species, E. varii POPESCU-GorJ \& CONSTANTINESCU, 1973, as a result of differences in the genitalia (POPESCU-GORJ \& CONSTANTINESCU 1973). So the current distribution of E. splendidalis includes the area from Macedonia to Asia. The records of E. splendidalis from Malta were identified as E. varii (SAMMUT 2005).

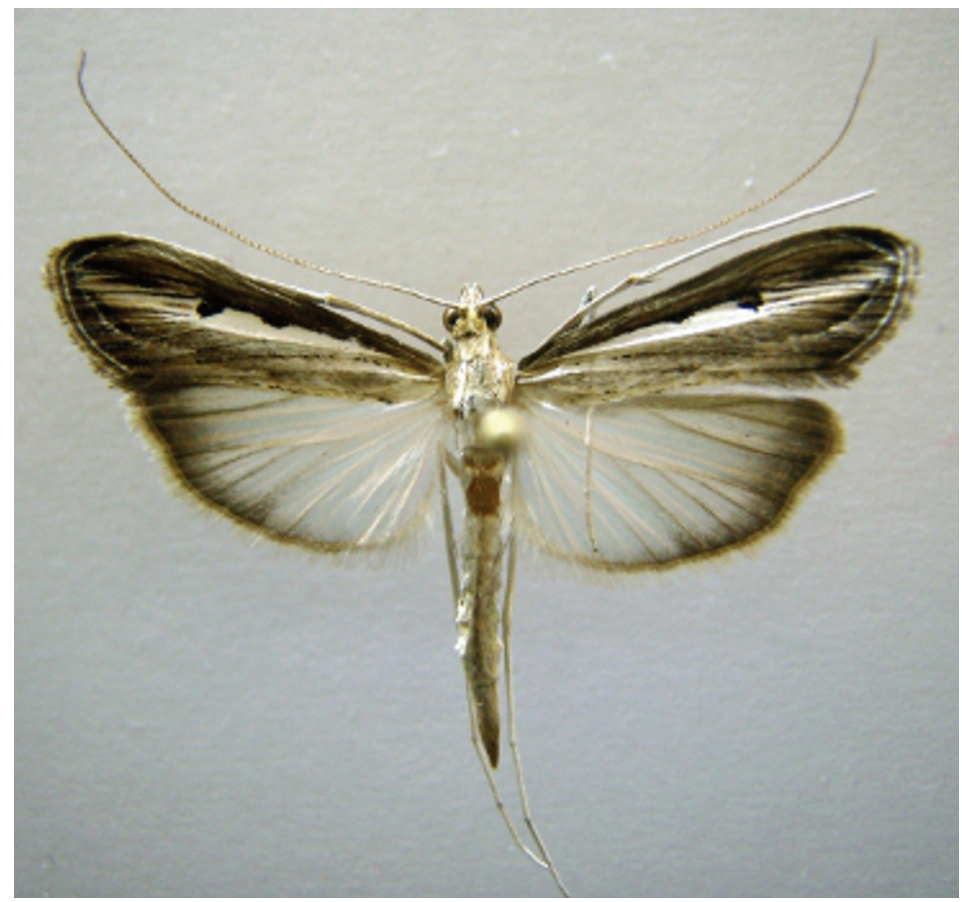

Fig. 2. Euclasta splendidalis (HERRICH-SCHÄFFER, 1848) - Croatia, $500 \mathrm{~m} \mathrm{~S}$ of Rogotin, 7.8.2012, leg. T. Koren.

The record from the Neretva Valley, Croatia is the westernmost distribution record of this species. The closest record to the Croatian population is that from Veles, Federative Republic of Macedonia, where KLIMESCH (1968) reports the finding of a single male specimen on 19.3.1918. This locality lies approximately $380 \mathrm{~km}$ distant from the records in the Neretva valley. The Microlepidoptera of Croatia are very poorly known, and atlases or checklists are virtually non-existent. The same applies to Bosnia and Herzegovina, 
Montenegro and Serbia, the countries lying between Croatia and the Federative Republic of Macedonia. So it is highly likely that this species also occurs in those countries, but is still unrecorded. Another possible explanation lies in the great diversity of the butterfly and moth fauna in the Neretva valley (KoREN, unpublished). For example, this is one of only two known localities where the African Monarch, Danaus chrysippus LinNaEus, 1758, has been recorded in Croatia (PERKOviĆ 2006, KUČINIĆ et al. 2011). Further systematic surveys of Croatia will probably result in many new species records and significant increases in known distributions.

\section{Acknowledgements}

I am very grateful to Ana Štih, Mitja Črne, Domen Trkov and Kaja Vukotić for their company and help during the field research.

\section{RERERENCES}

Fauna Europaea 2011. Fauna Europaea version 2.4. Web Service available online at http://www.faunaeur.org

HERRICH-SCHÄFFER G.A.W. 1847-1855. Systematische Bearbeitung der Schmetterlinge von Europa, zugleich als Text, Revision und Supplement zu Jakob Hübner's Sammlung europäischer Schmetterlinge. Vierter Band. Die Zünsler und Wickler, Regensburg, pp.: 1-288.

KLIMESCH J. 1968. The Lepidoptera fauna of Macedonia, IV. Microlepidoptera. Prirodonaucen Muzej Skopje 5, 201 pp. [in German].

KuČinić M., MinOci I., TVRTKović N., Šašıć M., Bojanić-Varezić D., Joković S., MaziJa M., POPIJAČ A. 2011. Butterfly Diversity (Insecta: Lepidoptera, Rhopalocera) of the Island of Mljet, Croatia. Proceedings of the Symposium Branimir Gušić Days, Mljet 2010. [In:] BENOvić A., DURBEŠIĆ P. (eds), pp.: 111-125. [In Croatian with English summary].

LeRaut P. 2012. Moths of Europe, Volume 3: Zygaenids, Pyralids 1. N.A.P. Editions, 599 pp.

Nuss M., Landry B., Vegliante F., Tränkner A., Mally R., Hayden J., Segerer A., Li H., Schouten R., Solis M.A., Trofimova T., De Prins J., Speidel W. 2003-2011. Global Information System on Pyraloidea. www.pyraloidea.org.

Nuss M., Speidel W., Segerer A. 2011. Fauna Europaea: Crambidae. [In:] Karsholt O., van NieuKERKEN E.J. (eds). Fauna Europaea: Lepidoptera, Moths. Fauna Europaea version 2.4, http://www.faunaeur.org.

Perković D. 2006. Danaus chrysippus (Linnaeus, 1758) (Lepidoptera, Nymphalidae, Danainae), a new species in the fauna of Croatia. Danaus chrysippus (LinNAEus, 1758). Natura Croatica 15: 61-64.

Popescu-Gorj A., CONSTANTINESCu A. 1973. New African species of Euclasta. Revue Roumaine de Biologie. Série de Zoologie 18: 393-401.

PoPescu-GorJ A., CONSTANTINESCU A. 1977. Revision of the genus Euclasta Lederer (Lepidoptera, Pyraustinae). A taxonomic and zoogeographic study. Travaux du Muséum d'Histoire Naturelle "Grigore Antipa", Bucuresti 18: 157-245.

SAMmut P. 2005. The correct identity of three Pyralidae moths from the Maltese islands (Lepidoptera: Pyralidae). SHILAP Revista de Lepidopterologia 33: 235-238.

Received: October 27, 2012

Accepted: October 31, 2012 